\title{
Revolution from Above in English Schools: Neoliberalism, the Democratic Commons and Education.
}

Since the formation of cultural sociology in the 1960s there has been a long history and interest in different styles of schooling as well as more democratic forms of pedagogy. Raymond Williams's (1962) idea of the long revolution urged the development of more dialogic forms of learning, seeking to develop common systems of education that broke with the patterns of a class society. Similarly Richard Hoggart (1958) had just a few years earlier argued for more critical forms of education, should the working-classes become 'corrupted' by mass culture. Both Hoggart and Williams promoted the idea of a common education system that offered children both a creative and civically oriented life as democratic citizens. If such an education system were to emerge, they claimed it would need the backing of the labour movement who seemingly had most to gain from an education system that did not merely train workers to labour, but sought to enable them to live more complex, democratic and educated lives. This approach is in response to the problem that the substantial gains of state education and the welfare state did not go far enough in breaking with the dominant logic of capitalism. When it came to understanding the resources spent on education, the dominant patterns of pedagogy and the choice of curriculum it was the needs of capital and the labour market that was given priority. For both Hoggart and Williams the labour movement in this respect needed to develop an educational agenda that insisted that working people were more than just labouring bodies, but could engage themselves in creative pursuits, democratic politics and develop educated interests.

However rather than the English education system being remade in more democratic terms what has become apparent in more recent times is that capitalism, in association with political elites, think tanks, charities and other moral entrepreneurs, is in the process of radically transforming the existing structure of schooling [1]. The recent break-up of the comprehensive school and its replacement over a relatively 
short period of time by an academy system might be better described as a 'short' rather than a 'long' revolution. The switch to academy status takes the institution out of local authority control, enhances flexibility over teachers' pay and conditions and gives head teachers enhanced autonomy in respect of curriculum and the length of the school day and terms. These features mostly enhanced the power of the state while granting a certain amount of local power to head teachers to shape the ethos of the school. If Williams thought that a genuinely democratic and learning society could only develop over time, after it had broken with the logic of authoritarian control from above, then more recent developments might suggest that the long revolution has gone into reverse. The development of academy schools, exam league tables and standardised testing has transformed the culture of English schooling.

\section{The New Left, Alterglobalisation and the Commons}

My argument is that if historically some on the cultural Left have sought to connect ideas of schooling with democracy then this narrative is failing in the current context. Instead a resurgent political Right (with some help from the ‘third way' Labour Party) is dominating the agenda on schools and education. In this respect, I seek to recover a notion of democratic education from thinkers associated with the New Left. The intellectuals of the New Left sought to develop a radical programme for education and society that was both critical of Lenininst Marxism and the histories and traditions of democratic and liberal socialism (Stevenson 1995, Kenny 1995). These histories and traditions have more recently been radicalised by the emergence of the alter globalisation movement. As Marianne Maecklebergh (2009) has argued the alter globalisations movements experiments with more 'direct' versions of democracy have their cultural and political roots in the radical 1960s and the New Left. The critique of vertical forms of power and control and the attempt to develop less hierarchical life styles and practices can be traced back to the New Left of the 1960s and even further back to more Anarchist traditions. However especially when compared to the New Left of the 1960s there is a more concerted attempt to critique the power of global corporations and the exclusionary practices of nation-states. Despite many voices that have argued that alter globalisation movements lacks a coherent critique of dominant institutional structures what is evident is a revolt against the rule of violent states and capitalism in favour of less exploitative and more democratic human relationships 
(Sitrin and Azzellini 2014). John Holloway (2002:18) has called the attempt to critique relations of domination across human society 'the anti-realism of anti-power'. The alter globalisation movement in its diverse struggles seeks to create a society where the dignity of everyone in their human diversity can be respected. While these are inevitably utopian ideas they would suggest that the struggle is not only against capitalism and the state, but also against all forms of dominating human relationships that seek to deny the autonomy and dignity of the other.

Despite some arguments that ideas of Left and Right are being eclipsed in the modern globalised world my argument takes a different tack (Giddens 1998). While ideas associated with the 'third way' have sought to dilute this opposition, the idea of the Left that includes both European and North American political traditions can still be defended. As Zygmunt Bauman (2007) argues the Left continues to have a future in as far as it seeks to improve the quality of life of the most vulnerable members of society while radically seeking to democratise and enhance the capacity of ordinary people to become citizens. There is a strong link between the idea of the democratic Left (accepting a good deal of multiplicity and difference) and critical accounts of pedagogy; as both seek to design institutions and styles of pedagogy that enhance democratic learning rather than either education for upward mobility or more conservative attempts to impose discipline and authority from above.

The original New Left of the late 1950s and early 1960s according to historian E.P.Thompson (1959/2014) was predominantly a movement of intellectuals and young people dissatisfied with the exclusive focus upon economic questions and interests by old Leftist organisations and the mainstream political parties. There was then at this moment an attempt to open up questions related to everyday life and culture which included education. This critical legacy, as I have indicated, has been further developed in the age of global corporate power, market failure, ecological fragility and the new technological wars after 9/11 (Klein 2000, Graeber 2014). These 'new' political intiatives have found multiple forms of expression in the Occupy movement, campaigns against sweat shop labour, environmentalism and opposition to militarism and imperial power. Despite the multiple agendas of the alter globalisation movement overwhelmingly the focus has been on the recovery and reinvention of democracy in an age of corporate control and neoliberal ideology (Castells 2012). The 'recovery' of democracy within the alter globalisation movement has found its most explicit expression through the attempt to defend the global commons against 
attempts by the state and capital to privatise our shared cultural and natural resources (Klein 2000). There is then a continual struggle over what we can be said to share and attempts made by the state or capitalism to impose hierarchical control from above (Harvey 2012:73). Neoliberalism, as we shall see, has a tendency to subject the commons to the rule of private property, enclosure and ideologies based upon competition. According to activist David Bollier (2014:157) the idea of the commons offers a critique of ideas of 'development' preferring to stress the importance of mutuality, shared space and respect for nature placing limits upon the expression of the market and control from above. These are all significant ideas of our times that build upon the ideas of the New Left but have been reinvented for our more market orientated and global times. Here after I have sought to describe the current crisis within education I seek to critically outline the implications these ideas have for how we think about learning more generally.

\section{Neoliberalism, the Crisis of Capitalism and Education}

Since the banking crisis and the election of the Conservative-Liberal Government in 2010 there has been a widespread recognition of the development of a new era in the English and wider global context. The so-called 'double-shuffle' of the previous New Labour government that sought to balance neoliberalism and more social democratic concerns has effectively come to an end (Hall 2003). The coalition government have a more overtly neoliberal bent. In this respect, there has been considerable debate concerning the internally contradictory nature of neoliberalism and the argument that it is differently inflected in a diversity of places and locations. For David Harvey (2005) the central tenet of neoliberalism is the idea that individual freedom is guaranteed by the market. This means that it is actively hostile to the welfare state, trade unions and other practices and institutions which might hold the market in check. Neoliberalism's hidden face is actually about the reassertion of ruling class power. It is large corporations who stand the most to profit from privatisation, the reduction of corporation tax, the enhanced mobility of capital and the promotion of entrepreneurialism. Further, neoliberalism acts not simply as a set of accumulation strategies on the part of capital, but also as a powerful hegemonic force that argues that markets and consumerism equal freedom. Especially since the 1980s and the 
aggressive capitalist governments of Thatcher and Reagan, neoliberalism has become the dominant common sense within elite circles. However while mostly agreeing with this account, a number of other critics have sought to offer a more nuanced understanding of neoliberalism. Stuart Hall (2011) has argued that despite its coherence around a number of features suggested by Harvey that in the English case at least it has been combined with an attachment to nationalism, homogeneous racial identity and social discipline. In seeking to understand neoliberalism as a popular ideological project (if not a hegemonic one) we need to understand how it couples an emphasis upon a certain version of national identity with the market. Further, that neoliberalism as a discursive construct and as a means of winning over popular consent appeals to the interests of 'tax payers' while seeking to punish those who are deemed to be 'dependent' on welfare benefits. These features have been prominent aspects in respect of the coalition government who have cut or abolished a number of benefits that have supported excluded or vulnerable groups during a period of rising unemployment and job insecurity. Despite the failings of the previous New Labour government the number of people claiming unemployment benefit fell while the state was able to offer increased levels of support to poor people with children and less well-off older people (Gregg 2011). As the main opposition within parliament the Labour Party has criticised the government cuts as 'too far, too fast', but they have similarly argued that in the context of 'austerity Britain' they would also have to make cuts, albeit not as severe as those demanded by the government.

Henry Giroux (2004) in this regard has powerfully suggested that we view neoliberalism as a form of public pedagogy. For Giroux (2004:106) the aim of neoliberalism is to "produce competitive and self-interested individuals vying for their own material and ideological gain'. It is not simply an economic theory (as should now be obvious) but an attempt through a variety of sites within popular culture, policy and other cultural institutions to produce economic calculating subjects. In this sense, neoliberalism seeks to establish a pedagogic role in respect of the majority of the population through the closing of common public spaces in the media and education, and an increasing focus upon financial reward, consumerism and more material benefits. Giroux's comments fit with changes in educational policy but also the rise of popular television progammes such as the Apprentice, Dragons Den and others that focus upon entrepreneurialism and business success (Couldry and Littler 2011). Further in the English context, as others have noted, much 'mainstream' 
popular entertainment has focused upon the so called 'shameless' lifestyles of the working-class who are seemingly lacking in taste and are vulgar (Tyler and Bennett (2010). The languages of 'chav's' and working class people as the abject Other has a long and complex history, but it fits rather well with the neoliberal emphasis upon upward mobility and market success being the prime aim of being human (Skeggs 2004). The sphere of education now seeks to explicitly foster upward mobility and 'aspiration' in such a way that it constructs those unable to compete as Other (Stevenson 2011)

However we should also remember that neoliberalism is less of a totalising ideology than some of these remarks might suggest. Andrew Gamble (2009) has pointed out that neoliberalism is founded upon a number of more contradictory features than has been apparent in the discussion thus far. Despite claims to the contrary, it actually requires a strong state to overcome resistance to the imposition of the rule by the market by those who perceive such a transformation not to be in their interests. On this point Wacquant (2010) argues that the growth of the prison population, the use of workfare and other punitive mechanisms have grown as a means of regulating human agency under the economic conditions of neoliberalism. The re-masculinised state seeks to distance itself from the role of caring for the bodies of the vulnerable by developing a more punitive and penalising legal system. The aim being to push poor citizens into low paid and insecure jobs by threatening to terminate benefits, while using prison as the ultimate social sanction for those who do not conform to these new requirements. The more aggressive state is partially masked by consumer freedoms for the majority and the individualisation of responsibility.

Missing from these accounts and others is how neoliberalism is also caught up with a language that seeks to arrest the moral decline of the nation. The idea of England trapped in a long term decline economically, politically and culturally, is not a recent phenomenon but has been reproduced over a number of decades (English and Kenny 2001). In this sense the discourse of 'declinism' is not directly produced by neoliberalism but has a longer historical link to the loss of empire and the fear of England losing global power and influence. While many of the critics of neoliberalism rightly emphasise the stress neoliberal discourses place on market calculation and the Othering of welfare claimants this does not appreciate the more explicitly moral language that seeks to remake modern society. The national 'decline' is to be addressed by transforming citizens into loyal and patriotic subjects who are 
entrepreneurial, optimistic and upwardly mobile beings who are increasingly focused upon education as a means of gaining financial reward.

\section{The Academies Programme: Revolution in English Schools}

If the meanings and practices of neoliberalism are to be more specifically located then more work is needed to unravel its different and often diverse projects. Here scholars who are interested in the shaping of state policy need to look at its formation over longer periods of historical time. This will enable us to view not only what is original and distinctive about neoliberalism, but also how it relates to the past and the way it is often connected to nationalist narratives and frameworks. In the English context, Paul Gilroy (2004) has argued that ideologies of decline are explicitly racialised as they seek to recall the theft of greatness and the loss of Empire. The melancholia of the English remains trapped in a period before cultural complexity and multiculturalism while nostalgically clinging the presumed greatness of Empire. There is a dominant discourse of Englishness under threat as it seeks to arrest imperial decline to arrest the nation's ‘downwardly mobile twentieth century' (Gilroy 2004:118). This can be witnessed in debates on immigration where the nation is presumed to be flooded by 'alien' cultures who are exploiting the English people's sense of fair play and justice. The 'decline' of English schools, on the other hand, is more explicitly concerned with the revival of a 'civilizing project' aimed at the transformation of the working-class and ethnically diverse population. As we shall see, such a project is far from being racially neutral given the emphasis that is placed on reimagining a specifically national narrative of decline. Further the recent attempt by the Coalition government to revive an educational language of authority, discipline and standards can also claim to be located in the anti-Enlightenment and conservative rhetoric of English writers like Edmund Burke (1999) who preferred the language of nation and tradition to the excessive talk of freedom that had accompanied the French revolution.

Especially significant in this respect has been the resurrection of Mathew Arnold by the previous minister for education Michael Gove. Michael Gove (2011b:2) described Arnold as a 'muscular liberal' who sought to introduce young minds to 'the best of what has been thought and written'. Here Gove sought to 'distance' himself from other politicians who are seemingly ashamed of their preference for high culture and try to speak of more popular tastes and concerns. 
Gove's authoritarian anti-populism recovers a world before 'postmodern relativism' where there were cultural standards and well established hierarchies. State schools in this regard sought to offer an undemanding education of low expectations where more 'popular' concerns might have been indulged or taken seriously. Academies in this reading have 'liberated' working-class children who yearn for 'rigorous intellectual discipline' and where they are unashamed to be seen enjoying Dickens and Shakespeare (Gove 2011b:5). Of course we may wish to challenge this view of working-class children with more complex understandings, but what matters in this setting is the authoritarian nature of this vision and narrative of liberation. Similar 'liberating' narratives are also offered by some of the entrepreneurial charities who are increasingly working in the education sector. Brett Wigdortz (2012:38) has written about how 'no child's educational success should be limited by their socio-economic backgrounds' and that it is the job of 'inspirational teachers' to 'break down barriers' to educational success. The dominant narrative in respect of schools is the need for a new range of institutions, pedagogic relationships and 'inspiring' teachers to 'turn around' a culture of failure. Notably narratives of liberation and freedom that have been historically associated with the Left are being incorporating by the political Right. It is relatively egalitarian comprehensive schools that are assumed to have been 'holding back' working-class children. However, as I have pointed out, the contradiction remains that the 'liberation' of children depends on extending state control of schooling. Of course this is all 'hidden' through ideological appeals to pragmatism. Michael Gove (2013:26) consistently defended his radical programme as being 'rooted in evidence', unlike his ideologically-driven opponents. These antipolitical features are also characteristic of the New Labour period as the increasingly managerial focus of the state sought to reform the public sector through the setting of targets. As Alan Finlayson (2003) has argued the fault line of New Labour was adaption to the technologically defined global economy while dismissing its opponents as conservatives.

In this context, Michael Gove's return to Mathew Arnold is interesting given Raymond Williams's (1958) argument that Arnold believed less in liberty than in the school's capacity to perfect the self. This argues Williams (1958:133) offers a deeply authoritarian view of education that has little concern with the self-understandings of the learner. For Williams (1958:303) a more democratic model should be wary of the idea that it is the role of educated culture to 'civilize' the brutish masses. A more 
democratic version of education should be concerned with fostering reciprocal human relationships and recognising that culture is an 'offering' and not 'an attempt to dominate, but to communicate, to achieve reception and response' (Williams 1958:303). These seemingly more subtle features are sacrificed in the zeal to impose the dominant culture on young working class people. Indeed Edward Said (1993:158) argues that 'the mob' that Arnold seeks to silence through culture is not only the lower orders but an ethnically diverse population who were resisting the imposition of colonial rule. In the return to Mathew Arnold and the insistence upon the virtues of 'civilisation' we can see not only neoliberalism, but also a certain nostalgic version of Englishness and an unashamed sense of cultural superiority.

What I have called the 'revolution from above' in respect of education is an attempt to arrest the failings and educational decline that has been presided over by the state sector. The fear that the Thatcher, New Labour and Coalition governments have sought to address is that the decline in educational 'standards' can be connected to 'our' loss of prestige both economically and politically. Here the masculinised state needs to 'save' our children from a world of chronic educational and moral decline. Since the Thatcher government of the 1980s the political Right has repeatedly sought to break up comprehensive education by promoting market reforms and consumer choice. Within much Rightist thinking comprehensive schools are blamed for 'holding back' aspiring working-class children who wish to 'get on'. The lack of progress made by working-class children is, according to this perspective, less to do with the class structure or a lack of cultural capital, and more because they have been failed by 'trendy' teachers and a culture of 'low expectations'. After the rise of the comprehensive school system the Right were seen to be nostalgically clinging to a previous era where 'bright' working-class children were sent to grammar schools and the 'less able' to more vocational (or elementary schools). More recently however some on the political Right (although not all) along with advocates of 'third way' social democracy have changed tack by seeking to exploit dissatisfaction with comprehensive schools to promote new structures and a new cultural vocabulary in relation to education.

If the idea of state education and comprehensive schooling is the product of the welfare state then the first systematic attempt to drive through market style reforms was made by Keith Joseph education minister in the 1979 Thatcher government. Joseph's attempt to impose a 'voucher' system on education, permitting 
parents to spend it either within private or state education, made little headway due to the opposition within trade unions and the wider labour movement (Ward and Eden 2009). The Thatcher government sought to attack the welfare state socialism of the post-war period promoting anti-trade union laws, privatisation, tax reductions and benefit cuts; this 'authoritarian populism' was more successful in some areas of civil society than others. Stuart Hall (1983:23) pointed out how at the time the "swing to the right' was in itself an attempt to respond to a perceived 'break-down' in law and order. There was at this juncture a call for social discipline in respect of market style reforms to be accompanied by a much tougher state. A more authoritarian popular 'common sense' had been imposed upon civil society from above by the media and political elites in order to answer the media-constructed 'cry for discipline' from below (Hall 1988:13).

Within the context of education it was the 1988 Education Reform Act that eventually began the process of implementing market reforms in the education system. This allowed parents the right to express a preference thereby potentially starving the least 'successful' schools of students and resources, beginning the process whereby the state increasingly brought education policy and schools under central control (Ward and Eden 2009). Education has been progressively transformed over this period from a matter for professional judgement to explicit state control (Pring 2012). The development of school league tables, the creation of Ofsted as an agency charged with the inspection of schools, the running down of the local authorities and the empowerment of head teachers have all considerably strengthened the role of the state in relation to education. The fear of the Conservative Right, and later, New Labour was that comprehensive education had failed to promote a competitive and entrepreneurial society that would maintain the nation's position as a major economic power in the world. The neoliberal settlement has decisively moved the education agenda away from the control and judgement of teachers to a world where educationalists are subjected to performance management intiatives of the state (Olsen et al 2004:270). Further New Labour explicitly sought to reject the idea that poverty and class could be used as an 'excuse' for poor educational attainment (Power and Whitty 1999). It was during this period that comprehensive schools became progressively dismissed as being unable to provide consumer choice, upward mobility and exam success (Stevenson 2011). The 'need' to reform education in this setting was explicitly linked to the 'third way' requirement to both think 'positively' about 
globalisation while also ensuring that Britain was 'fit' to compete globally within new and emerging markets (Giddens 1998). However critics were concerned that the new emphasis upon upward mobility not only instrumentalised education, but ultimately left behind those deemed less able to compete (Tomlinson 2006).

It was this sense of the 'decline' of England in more global terms that can be linked to the notion that the nation was morally broken. This is a discourse that persistently points to the collapse of English society whose 'moral fibre' has become rotten, largely due to the impact of the inadequate behavior of the poorest members of society. The current Prime Minister David Cameron has sought to connect the idea of 'Broken Britain' to his 'passion' the 'Big Society'. While many have complained that this concept is quite vague it is based upon the idea of individuals taking the necessary action to 'fix' moral decline. This is a call for more people to become actively involved in voluntary organisations seeking to arrest the social and moral decline of society. This theme was at the core of the coalition government's understanding of the 2011 English riots which prime minister David Cameron described as a 'wake-up call' to a society built upon 'Irresponsibility. Selfishness. Behaving as if your choices had no conseqeunces. Children without fathers. Schools without discipline, reward without effort' (Stratton 2011). The need for moral reform to arrest the social breakdown of society requires not only the ethic of personal responsibility but also the return of authority and discipline. Notably England is seen as broken because authority has become too 'soft' and has lost its moral compass. These features can be attached to the return of a 'tough' communitarian agenda originating in the United States that wishes to talk less of liberal freedoms and rights, and more about responsibility towards society, the family and religion. The fragmentation and moral breakdown of the social order in much of this thinking has been caused by citizens being granted too many rights and a general sense of moral permissiveness. Similar political ideas are available across the political spectrum with some Left intellectuals seeking to reclaim the 'Big Society' agenda for themselves, although this time with a strong emphasis upon the role of the state (Glasman 2011).

The idea of moral and civic decline is central to the development of Academy schools. These were initially established by the New Labour government to address 'failing' schools and then radically extended by the Coalition government. Andrew Adonis (2012), one of the key policy architects of the academies programme (and now a Labour Lord), has argued for the need to move away from a system that 
divided comprehensive and private schools into two different sectors. Instead the state is called to regulate private institutions such as fee paying schools and 'free schools' while academies are legitimated by the brake that was placed on social mobility by comprehensives. This shift, argues Adonis, will help foster a national citizenship and end the old educational apartheid. If the comprehensive school system stands accused of having low expectations of working-class children then the academy schools are largely independent from local authority control, increasingly under the direction of head teachers and are explicitly charged with raising levels of educational attainment. Under the guidance of 'powerful' head teachers they are more able to weaken the bargaining position of teaching unions and impose upon schools new levels of order and discipline. Adonis's book notes approvingly the creation of Mossbourne Community Academy (opened in 2004) where students are expected to recite inspirational mantras, stand when teachers enter the room and adhere to an uncompromising set of rules and regulations. These new institutions along with school league tables, nationally regulated school curriculum and an attitude of 'aspiration' and 'no excuses' for failure are all charged with the driving up of exam performances particularly amongst poorer more working-class students. Such policies, Adonis hopes, will provide the basis for a more fluid and less class-based society. Similarly Michael Gove (who has now been replaced by Nicky Morgan) (2014) has proposed that academy schools (along with tougher and more tests, more discipline, powerful heads, international standards and ten hour school days) can help erode 'the Berlin Wall' between public and private schools. Previously Michael Gove (2011) explicitly connected lawless behavior witnessed in the English riots to the decline in discipline in schools. Here academies will allow 'inspirational' teachers in an atmosphere of 'strict discipline' to focus young minds on educational (and economic) success rather than rioting in the street. The academies will not only help foster competitiveness but also reverse the decline of the nation. The political Right (and many of those involved in the 'third way') have organised an educational narrative around the idea of both economic and moral decline that requires the invention of a new, much 'tougher' approach to education with a heavy emphasis upon authority.

However prominent critics of the academy system like Melissa Benn (2011) have pointed to the attack on teacher's terms and conditions, autonomy, local democracy and perhaps most important of all the idea that comprehensive's sought to educate children from different class backgrounds together. Here Benn notes a 
consistent campaign against comprehensives mainly focusing upon their failings (which are exaggerated) and having very little to say about the need to provide a genuinely inclusive education. Academies are less concerned with a culture of inclusivity, but tend to have a more explicit focus on exam success. If the comprehensive notion of the good society was of a democratic community they have been replaced by social engineering for upward mobility. Many on the political Left (both on the fringes of and outside Labour Party policy circles) have sought to defend the idea of the comprehensive through its connection to the idea of democratic schooling. These ideas take inspiration from John Dewey's (1916) work on the common school that provides a meeting ground for people from different social and religious backgrounds. A democratic school in this setting would be for the benefit of all the community and would enable students to learn through communicating across boundaries. There has been a persistent attack on the idea that schools should be places of exploration and liberty as this has simply left 'the young' without a secure moral compass. Stephen Law (2006) has commented that if a genuinely liberal approach to education involves encouraging children to think and reason for themselves the problem is that in the context of much communitarian philosophy this has been labeled as the culture of moral decline and selfishness. It is the more exploratory liberalism of the 1960s that is being rejected in favour of a more authoritarian approach to schooling and morality. The so called 'relativism' of a genuinely liberal approach to education is equated with moral laxity and an 'excuses for failure' culture that was presumed to exist in comprehensive schools. Academy schools are about the long term erosion of democracy through the control of the state from above as opposed to the narrative of lawlessness, decline and the need for authority. Notably, for the time being at least, it is the story offered by the political Right and the 'third way' Left that is in the ascendency. In the context of decline, moral decay and increasing global competiveness the Left's concerns with the erosion of democracy has not struck a chord with the wider public in the way that other concerns about neoliberalism have done.

\section{The Democratic School and the Commons}

Within the English setting the 'culture war' over schools tends to position defenders of academies as the bearers of standards, intellectual rigour and achievement whereas 
the supporters of comprehensives are more likely to speak of the values of democracy and inclusivity. However as we have seen this situation is now considerably more complex after the arrival of' third way' style social democracy. In this respect, voices on the democratic Left need to continue to speak for values other than those determined by the needs of financial markets and the entrepreneurial society. If there is indeed a cultural war within European societies it is less a struggle of different civilisations in the way that has been suggested by the war on terror, and more long standing cultural conflicts between authoritarianism and democracy that can be traced back to the Enlightenment (Bronner 2004,Todorov 2009). The main problem at the current juncture is that those who seek to resist the transition from comprehensive schools to academies simply end up defending the comprehensive model rather than exploring more radical democratic arguments.

Wendy Brown has criticised Left strategies that seek to cling to tradition or previously held versions of the good society long after the debate and society has moved on. Brown (2005: 54-55) argues that 'loss can take shape as melancholic, including the straight forward possibilities of idealizing a lost object as it was never idealized when it was alive'. Missing from many debates on comprehensive schools is an appreciation that many were places where working class children literally failed and 'learned to labour' (Willis 1977). In addition we also need to appreciate that the era of welfare capitalism has been replaced by a global information based capitalism. As Hardt and Negri (2000) and Berardi (2012) have argued postmodern capitalism requires mobile, flexible and computer literate workers for the economy of the $21^{\text {st }}$ century. Education becomes instrumentalised as it becomes one of the means to attract capital and investment in a deterritorialised economy. In this respect, Berardi (2012: 31) remarks if neoliberalism uses the language of freedom it does so as it 'submits production and social life to the most ferocious regulation, the mathematization of language'. Social life within this new matrix is subjected to the logic of calculation, impersonality and the continuous measurement of performance. As Michael Fielding and Peter Moss (2011) argue education is being progressively converted into a form of technical management where its primary role is to serve the economic system. The languages of grade improvement, efficency and measurable outcomes have progressively driven out more emancipatory concerns

Within this setting an alternative Left strategy can-not simply defend the existing institutions, but needs to begin by alterting wider publics about what is being 
lost from education. Stanley Aronowitz (2008) argues in this setting that a reemphasis upon democratic forms of education requires a rejection of a learning model that seeks to down-grade creativity and critical thinking for the majority. In this respect, we should seek to distinguish schooling from education (Aronowitz 2008:19). Such a view takes the debate on education beyond issues related to the equality of opportunity that mainly act as a smokescreen for the continuation of the class structure while viewing failure in Darwinian terms. More recently Henry Giroux (2004) has argued that figures such as Raymond Williams and John Dewey amongst others argued for a common democratic citizenship in the face of the power of money and corporate interests that sought to reshape the education system in more malleable terms. The promotion of a common culture of questioning and democratic responsibility needs to be promoted instead of a marketised logic of hierarchical learning, continuous testing and standardisation. These visions remain crucial and call for both resistance within education and the imagining of democratic alternatives. However in the age of financial capital and the neoliberal state we need to be more radical in our thinking than simply expecting to return to the social state of the previous period.

Zygmunt Bauman (2000:51) reminds us that a more emancipatory agenda today requires increasing levels of interconnection between public space and public power. If the market offers competition and failure and the individualised life of consumption then radical politics requires a vision that links questions of education to an alternative society. Within the context of neoliberal England and the assault on education the dream of a different society requires that we mutually reimagine the state and the education system together. In order to begin this task my argumentative strategy is that rather than simply defending comprehensive schools or joining in the rush to embrace the new academy schools the cultural Left need to begin the task of linking questions related to education to debates within the alter globalisation movement. The question posed by alter globalisation movements is whether we can reimagine learning without a system of authoritarian control imposed from above and the dominance of the language of measurable outcomes. Such a view would need to start with the argument that the most important education is self-education and that if we are not to harm the dignity of future citizens then we need to radically shift away from a meritocratic view of education that sorts and grades people into status hierachies. As Ivan Illich (1972) originally argued we also need to question the 
assumption that all learning is the direct result of the instruction received within educational institutions. Much learning goes on within families, local libraries, through the media of mass communication and within society more generally. This argument is also linked to the need to question the assumption that within learning everything should or indeed can be easily measured. As Illich (1972: 40) commented in a 'schooled world the road to happiness is paved with a consumer's index'. This is a reference to the globalised world of the $21^{\text {st }}$ century that understands education through a rubric of measurable outcomes with students and nations competing with one another in a global skills race. The cultural Left needs to develop a systematic critique of the neoliberal fictions that have become produced through a world of league tables thereby reducing education to the level of a consumer satisfaction survey. The consequence of these arguments is not necessarily to cancel all compulsory forms of education as engaged levels of citizenship are not actually possible without certain 'functional' capacities such as being able to read and write. However the 'humanisation' of the education system would require a move away from a standardised and intensely state regulated world based upon size and institutional conformity. The democratic decentralisation of education away from the priorities of the neoliberal state would not only be built upon enhanced professional autonomy for teachers, but would also require the eventual evolution of different and more autonomous educational institutions. Paul Goodman (1964) was not only critical of Dewey for not defending the right of the child not to engage in institutionalised education, but he also argued that a more effective learning environment would be supported by much smaller scale schools. This would promote a greater level of community that allowed teachers to more carefully respond to the individual needs of the children. These ideas are of course similar to other radical thinkers on education such as Erich Fromm (1941) and Cornelius Castoriadis (2011) who argued that the ultimate concern of education is with the development of the self and the necessary skills for democratic citizenship but that these are threatened by institutions that seek to reduce the individuals to the status of a cog in a huge machine. If the world of 'measurable outcomes' offers a degree of security to the host society it has a direct impact upon the freedom of the citizen to engage in the practice of self-education. Instead of becoming an automaton of the education system a society built upon freedom would require other priorities. The 'hidden curriculum' of the school then requires individuals that are compliant and 'positive' rather than being able to think 
critically for themselves. More critical forms of thinking are much more likely to flourish in a world where the teachers themselves are more autonomous and there is much less emphasis upon large homogenous schools geared to producing certain kinds of people for the labour market.

Arguably these features are in tune with the current thrust of the alter globalisation movement that seeks to foster a world that minimise the domination of capital and control from above. However the prospect for the future emergence of a democratic commons within schools will only become possible if we begin to transform other relationships within society. Juliet Schor (2010) has suggested that in the age of neoliberalism and ecological crisis there needs to be a redefinition of what we mean by 'wealth' by seeking to revalue free time, reduce working time, reutilize education to learn new skills while rebuilding the social state that would take care of people when they are vulnerable. This more sustainable model of the human future would inevitably depend upon more local economic relationships thereby sustaining a shared sense of community. These features are related to other visions of the future imagined by Andre Gorz (1999) and Bookchin (2014) who sought to provide the basis for a more co-operative society, redefine work and leisure time while guarenteeing a basic income for all. Education that has become detached from ideas of global economic competition or national decline could reclaim its soul by offering citizens the chance to learn what they wanted to learn.

Citizens have been progressively disconnected from a meaningful education through systems that are increasingly controlled from above and linked to requirements of capitalism. In the context of the radical New Left E.P.Thompson (1957/2014) made an impassioned argument against a state centred Stalinist ideology that dealt in theoretical abstractions while seeking to control society through the state. Thomson's libertarian argument sought to warn against the dangers to human freedom in a world that was progressively controlled from the centre by capital or the state. Such a society robbed human-beings of a shared sense of agency and morality that would enable them to become self-educative beings. These warnings are also pertinent for our authoritarian and capitalist times as the meaningful practice of democracy progressively withers on the vine. Ivan Illich (1992) recognised that in this regard that the idea of the commons was not only a form of resistance against the idea of enclosure, but was a place where citizens could learn, gain an income and play without becoming a resource for capital. The problem being that under neoliberalism 
that education is progressively converted into a resource for capital rather than being a place of human becoming. If the cultural Left are to remain relevant to the future then need to rediscover a more decentralised and democratic imagination.

\section{Notes}

1. Here the focus of the text is on the English rather than the British debate in respect of schools. This is mostly because the devolved assemblies of Scotland and Wales have a role in the governance of schools as well as different histories and traditions of schooling. For example, whereas Wales currently has no academy schools this is not the case in Scotland which differs from the English system in other respects.

\section{Bibliography}

Adonis, A. (2012) Education, Education, Education: Reforming England's Schools, London, Biteback Publishing.

Arnold, M. (1869/1970) Selected Prose, London, Penguin.

Aronowitz, S. (2008) Against Schooling, Boulder, Paradigm Publishers.

Bauman, Z. (2000) Liquid Modernity, Cambridge, Polity Press.

Bauman, Z. (2007) 'Has the future a left?', Soundings, Issue 35 (Spring).

Benn, M. (2011) School Wars: The Battle for Britain's Education, London, Verso.

Berardi, F. (2012) The Uprising: On Poetry and Finance, Cambridge, MIP Press.

Bollier, D. (2014) Think Like a Commoner, Gabriola Island, New Society Publishers.

Bookchin, M. (2004) Post-Scarcity Anarchism, Edinburgh, AK Press.

Bronner, S. (2004) Reclaiming the Enlightenment, New York, Columbia University

Press. 
Brown, W. (2005) Edgework: Critical Essays on Knowledge and Politics, Princeton, Princeton and Oxford University Press.

Burke, E. (1999) Reflections on the Revolution in France, Oxford, Oxford University Press.

Castells, M. (2012) Networks of Outrage and Hope, Cambridge, Polity Press.

Castoriadis, C. (2011) Postscript on Insignificance, London, Contiuum.

Couldry, N. and Littler, J. (2011) 'Work, Power and Performance: Analysing the

'Reality' Game of the Apprentice', Cultural Sociology 5(2) pp263-279.

Dewey, J. (1916) Democracy and Education: An Introduction to the Philosophy of

Education, New York, The MacMillan Company.

English, R. and Kenny, M. (2001) 'Public intellectuals and the quation of British decline', British Journal of Politics and International Relations 3(3) pp 259-283.

Fielding, M. and Moss, P. (2011) Radical Education, London, Routledge.

Finlayson, A. (2003) Making Sense of New Labour, London, Lawrence and Wishart.

Fromm, E. (1941) Escape from Freedom, New York, Avon Books.

Giddens, A. (1998) The 'third way': New Politics for a New Century, Cambridge, Polity Press.

Gilroy, P. (2004) After Empire, London, Routledge.

Glasman, M. (2010) 'Society not State: The Challenge of the Big Society', Public Policy Research, June/August 2010 pp59-63.

Gorz, A. (1999) Reclaiming Work, Cambridge, Polity Press.

Gove, M. (2011a) 'Speech to Durham Academy', www.michealgove.com/news/micheal-goves-speech-durand-academy accessed 12.12.12.

Gove, M. (2011b) ‘A Liberal Education' www.michealgove.com/news/micheal-govespeech-cambridge-university. Accessed 12.12.12.

Gove, M. (2013) 'Wrong again, Ed', The Guardian newspaper, 1 August 2013, p26.

Gamble, A. (2009) The Spectre at the Feast, Basingstoke, Palgrave MacMillan.

Giroux, H. (2004) The Terror of Neoliberalism, Boulder, Paradigm Publishers.

Giroux, H. (2011) On Critical Pedagogy, London, Continuum.

Giroux, H. (2012) Disposable Youth, London, Routledge.

Goodman, P. (1971) Compulsory Miseduction, London, Penguin.

Graeber, D. (2014) The Democracy Project, London, Penguin. 
Gregg, P. (2011) 'New Labour and Inequality', in Diamond, P. and Kenny, M. (eds)

Reassessing New Labour, Oxford, Wiley-Blackwell pp 16-30.

Hall, S. (1983) 'The Great Moving Right Show', in Hall, S. and Jacques, M. (eds) The Politics of Thatcherism, London, Lawrence and Wishart.

Hall, S. (1988) The Hard Road to Renewal, London, Verso.

Hall, S. (2003) 'New Labour's double-shuffle', Soundings 24 pp10-24.

Hall, S. (2011) 'The Neo-Liberal Revolution', Cultural Studies 25(6) pp705-728.

Hardt,M. and Negri, A. (2000) Empire, Cambridge, Harvard University Press.

Harvey, D. (2005) A Brief History of Neoliberalism, Oxford, Oxford University

Press.

Harvey, D. (2012) 'The Creation of the Urban Commons', in Rebel Cities, London, Verso pp67-88.

Hoggart, R. (1958) The Uses of Literacy, London, Pelican.

Holloway, J. (2002) Change the World Without Taking Power, London, Pluto Press.

Illich, I. (1972) Deschooling Society, London and New York, Marion Boyars.

Illich, I. (1992) 'Silence is a Commons', In the Mirror of the Past: Lectures and

Addresses 1978-1990, New York, Marion Boyars pp47-54 .

Kenny, M. (1995) The First New Left: British Intellectuals After Stalin, London,

Lawerence and Wishart.

Klein, N, (2000) No Logo, London, Flamingo.

Law, S. (2006) The War for Children's Minds, London, Routledge

Maecklelbergh, M. (2009) Will of the Many: How the Alterglobalisation movement is changing the face of democracy, London, Pluto Press.

Nussbaum, M. (2010) Not For Profit: Why Democracy Needs The Humanities,

Princeton, Princeton University Press.

Olsen, M. et al (2004) Education Policy, London, Sage.

Pring, R. (2012) '60 years on: The Changing Role of Government', British Journal of Educational Studies 60(1) pp29-38.

Rousseau, J. (1762/1979) Emile or On Education, London, Penguin..

Said, E. (1993) Culture and Imperialism, London, Chatto and Windus.

Schor, J.B. (2010) True Wealth, London, Routledge.

Skeggs, B. (2004) Class, Self and Culture, London, Routledge.

Sitrin, M. and Azzellini, D. (2014) They Can't Represent Us!, London, Verso.

Stevenson, N. (1995) Culture, Ideology and Socialism, Aldershot, Avebury. 
Stevenson, N. (2010) 'Education, neoliberalism and cultural citizenship: Living in ' $\mathrm{X}$ Factor' Britain', European Journal of Cultural Studies pp341-358.

Stevenson, N. (2011) Education and Cultural Citizenship, London, Sage.

Thompson, E.P. (1959/2014) 'The New Left', in Winslow, C. (eds) E.P.Thompson

and the Making of the New Life, New York, Monthly Review Press pp119-134.

Thompson, E.P. (1957/2014) 'Socialist Humanism', , in Winslow, C. (eds)

E.P.Thompson and the Making of the New Life, New York, Monthly Review Press pp48-87.

Todorov, T. (2009) In Defense of Enlightenment, London, Atlantic Books.

Tomlinson, S. (2006) Education in a Post-Welfare Society, Maidenhead, Open

University Press.

Tyler, I. and Bennett, B. (2010) 'Celebrity chav: Fame, femininity and social class', European Journal of Cultural Studies 13(3) 375-393.

Wacquant, L. (2010) 'Crafting the Neoliberal State: Workfare, Prisonfare, and Social Insecurity', Sociological Forum 25(2) pp197-220.

Ward, S. and Eden, C. (2009) Key Issues in Education Policy, London, Sage.

Wigdortz, B. (2012) 'Teachers should never lose sight of their pupils potential for greatness', The Guardian newspaper, Tuesday 11 December 2012 p38.

Williams, R. (1958) Culture and Society 1780-1950, London, Pelican.

Williams, R. (1962) The Long Revolution, London, Pelican.

Williams, R. (1980) Culture and Materialism, London, Verso.

Willis, P. (1977) Learning to Labour, Farborough, Saxon House. 